\author{
Walter Dill Scott: Pioneer Industrial Psychologist \\ Author(s): Edmund C. Lynch \\ Source: The Business History Review, Vol. 42, No. 2 (Summer, 1968), pp. 149-170 \\ Published by: The President and Fellows of Harvard College \\ Stable URL: http://www.jstor.org/stable/3112213 \\ Accessed: 04/02/2014 13:54
}

Your use of the JSTOR archive indicates your acceptance of the Terms \& Conditions of Use, available at http://www.jstor.org/page/info/about/policies/terms.jsp

JSTOR is a not-for-profit service that helps scholars, researchers, and students discover, use, and build upon a wide range of content in a trusted digital archive. We use information technology and tools to increase productivity and facilitate new forms of scholarship. For more information about JSTOR, please contact support@ jstor.org. 
By Edmund C. Lynch

ASSISTANT PROFESSOR OF MANAGEMENT

UNIVERSITY OF TEXAS, AUSTIN

\title{
Walter Dill Scott: Pioneer Industrial Psychologist
}

\begin{abstract}
In the history of personnel management and salesmanship in the United States, the concepts and techniques developed by Professor Walter Dill Scott of Northwestern University have been pervasive. As an introduction to Scott's ideas and to his activities, Professor Lynch summarizes his contributions in the application of psychology to business problems.
\end{abstract}

Walter Dill Scott (1869-1955) was a man ahead of his time. He pioneered in applying the concepts, the knowledge, and the controlled experimental method of psychology to business problems. But his work has been largely forgotten today, obscured by the passing of time and by his later accomplishments as president of Northwestern University. Scott worked initially with businessmen on problems of salesmanship and personnel management. He began with the analysis and design of advertising copy, but as his view of the nature of selling enlarged, his interest turned to the selection of salesmen, and then to vocational selection in general. He constructed the system used by the United States Army in World War I to classify and assign some $3,000,000 \mathrm{men}$, and, after the war, he applied the knowledge and experience thus gained once again to the needs of business. As one of the first academicians in America to specialize in industrial psychology, and as an important influencer of business practice, Scott is worthy of the attention of historians.

Born May 1, 1869, Scott grew up on the family farm near Normal, Illinois. At the age of fourteen he assumed sole responsibility for managing that farm when his elder brother John left for Northwestern University to become an educator. Walter later decided that he, too, would become a teacher and entered Illinois State Normal University to prepare himself. In the fall of 1891 he entered Northwestern University on a four-year tuition scholarship and, in order to support himself, tutored students in grammar and mathematics. During the last two years as an undergraduate he

Business History Review, Vol. XIII, No. 2 (Summer, 1968). Copyright (C) The President and Fellows of Harvard College. 
also found time to teach Americanization classes at the Northwestern University Settlement House. He was president of his senior class in 1895 and a member of Phi Beta Kappa. ${ }^{1}$

Two of his teachers who had particular influence on Scott's career were George A. Coe and Robert M. Cumnock. Coe taught psychology which at Northwestern was then a subdivision of philosophy. He was deeply concerned about the problems of the practical world - human relations and human potentialities - and was later to influence Scott in his choice of psychology as a field and to encourage his study of the psychology of advertising. Cumnock taught Scott elocution and stimulated an abiding interest in public speaking. ${ }^{2}$

After graduating from Northwestern, Scott entered McCormick Theological Seminary in Chicago and studied for three years preparing for an assignment as a missionary-teacher in China. This call did not come and he then decided to study psychology. In this decision he was influenced by Coe and by the stir in academic circles over Wilhelm Wundt's psychological laboratory at the University of Leipzig. He married and sailed for Germany in the summer of 1898.

Scott earned his Ph.D. in psychology under Wundt in 1900 and returned to Northwestern University as an instructor in psychology and pedagogy, and as director of the psychological laboratory which he established. En route to Northwestern he studied briefly the operation of the laboratory at Cornell University under Edward B. Titchener, professor of psychology. By 1907 Scott was a full professor of psychology at Northwestern, and when the School of Commerce was founded in 1909, he received the additional title, professor of advertising.

Contrary to the notions of some of his colleagues that anything practical was beneath the dignity of the academic realm if not a disgrace to the profession of true science, Scott early visualized social benefits from the practical application of psychology and foresaw its widely expanding future. ${ }^{3} \mathrm{He}$ was one of a relatively small group of psychologists active in applying the experimental techniques of psychology to business problems. His brother John, who taught Greek at Northwestern did not agree with him on this point for John was a zealous believer in learning for learning's sake. ${ }^{4}$

${ }^{1} \mathrm{~J}$. Z. Jacobson, Scott of Northwestern (Chicago, 1951), 31.

2 Ibid., 77.

3 Ibid., 44

4 Ibid., 48. 
Late in 1901, Thomas L. Balmer, western advertising manager for the Butterick magazines, persuaded Scott to address a group of advertising men on how psychology might be used in advertising. Balmer had previously asked Hugo Muensterberg of Harvard University and Edward L. Thorndike of Columbia University but both had declined because of their reluctance to apply their ideas to business problems. Balmer had then approached Coe, and as Coe was busy at that time, he suggested Scott. Scott accepted and Coe gave his approval as head of the Department of Philosophy and Psychology.

Scott spoke to The Agate Club at their annual dinner in Chicago on December 20,1901. Since attracting attention was the common aim of all advertising, said Scott, he had selected as his topic "The Psychology of Involuntary Attention as Applied to Advertising." Scott began his talk by saying that psychologists had learned that a person's span of attention was narrow and that only a few things could be attended to at one time. He stated that attention was governed by six principles, the first being that the power of any object to force itself on our attention depended upon the absence of counter-attractions. He described a psychological experiment in which subjects were shown a variety of symbols displayed for a fixed time. The results demonstrated that an average person could observe no more than four objects at one time. This was one reason why a full-page advertisement was so effective.

Secondly, the attention value of any object depended upon the intensity of the sensation aroused. Scott cited the work of the psychologist Harlow Gale which demonstrated that the color of ink and the size of type influence attention. Scott's third principle was that the attention value of an object depended upon its contrast with whatever preceded or followed it. However, this contrast should be congruous for an advertisement to be effective. His example was the use of white letters on a black background.

The fourth, fifth, and sixth principles were that the attention value of an object depended upon: repetition, ease of comprehension, and intensity of aroused feelings. While contrast and repetition would seem to conflict, they could be used together. He suggested a constant recognizable feature in an advertisement in which details were varied from time to time. As for ease of comprehension, a picture was more effective than words. Above all, the ideal advertisement should appeal to the feelings, interest and desires to the sentiment as well as to the intellect. This called for the work

5 Ibid., 72. 
of a true artist to excite pleasurable feelings. Scott concluded his talk by saying that before the psychology of advertising could be considered complete there were a dozen or more topics that needed investigation, such as the association of ideas, suggestion, and mental imagery.

The response of Scott's audience of businessmen was highly encouraging. The editor of Agricultural Advertising said that Scott's address "was the most suggestive thing uttered on advertising in many a day," and he was impressed by Scott's firm grasp of the subject and his keen appreciation of the importance of advertising. ${ }^{6}$ Also impressed by Scott's remarks, John L. Mahin of the Mahin Advertising Company offered to publish a monthly magazine if he would write a series of articles on the topics suggested in his talk. Twenty-six articles were ultimately published in Mahin's Magazine, the first twelve being the basis for Scott's first book, The Theory and Practice of Advertising. ${ }^{7}$

Scott used a variety of methods in the preparation of his articles: armchair applications of psychology; controlled experiments using his friends and students as subjects to develop his information; and, the questionnaire to gather information on the actual experience of businessmen for analysis. ${ }^{8}$

His lifelong interest in elocution also led naturally to a study of the psychology of the spoken word, and resulted in a series of articles for Talent designed to help business men become effective speakers. Talent was the official publication of the Association for the Advancement of Speech Arts. ${ }^{9}$

Scott also integrated his teaching and his work in business by involving his students. As an example, he suggested to Joseph Schaffner, Sr., in 1909, that he use the symbol of a man on horseback in Hart, Schaffner \& Marx advertising to suggest rugged yet refined manliness. When the advertisement appeared, Scott took a supply of the papers to his class and tested this idea on his students. ${ }^{10}$

Between March 1910 and October 1911, Scott wrote eleven arti-

BW. D. Scott, "The Psychology of Involuntary Attention as Applied to Advertising," Agricultural Advertising, IX (January, 1902), 10 and editorial comment, 4. Scott later noted that, while Gale was studying involuntary attention he was not interested in its application. W. D. Scott, R. C. Clothier, and W. R. Spriegel, Personnel Management (5th ed., New York, 1954), 242.

T W. D. Scott, The Theory and Practice of Advertising (Boston, 1903). Scott said later that this book created a new era in the science of advertising, The Psychology of Advertising (Boston, 1908), 255. The later book resulted from the entire series.

8 One chapter in The Psychology of Advertising considered the strengths and limitations of the questionnaire with an example.

9 Published later as The Psychology of Public Speaking (Philadelphia, 1907) by the publishers of Talent. Scott said that he knew of no earlier work under this title (p. 11).

${ }^{10}$ Jacobson, Scott, 53.

\section{BUSINESS HISTORY REVIEW}


cles for System under the title "The Psychology of Business." These were inspired by the idea that man was the neglected factor in business - that while great progress had been made in the mechanics of production and distribution, little progress had been made in the ability to select and supervise men. Scott's concern was with the importance of attitudes in motivation and productivity. It was his belief that the typical worker did far less work than he was capable of doing because managers did not know how to select workers or how to supervise them. Scott considered that improvement in productivity would be beneficial both to the employee and the employer, saying that "An efficient and contented employee has a positive money value to any employer. To hold him and keep him effcient, his personal comfort and needs should be considered in every way not detrimental to the company's interests." 11 These needs were both psychic and economic. Among the psychic needs were an opportunity for self expression at work, social approval, and work that appealed to the worker as something important and useful. He had queried businessmen who had been especially successful in dealing with their employees and had based his suggestions, in part, on their demonstrated practice. Edward K. Strong, Jr., then a lecturer in psychology at Columbia University, said in his review of Scott's book resulting from these articles that the attitude of businessmen toward psychology and what it could do to help with their problems had undergone "enormous change" in the past few years. He gave Scott much of the credit for this change saying that he was known to nearly every advertising man in the country. ${ }^{12}$

In the psychology of business Scott explained how imitation could assist in the training of new workers and in stimulating the performance of all workers by providing examples worthy of emulation. Competition could be a powerful force in stimulating performance, but it was not suited for all occasions. Loyalty would increase organization power, but it was difficult to achieve because it depended upon the attitude of the employer toward his men. It took more than fair wages, reasonable hours, and good working conditions to encourage loyalty. The important thing was for the employer to have a sincere interest in the welfare of his men and to make each employee feel that his job was essential and worthy of his best efforts. The square deal was an indispensable ingredient.

11 W. D. Scott, "The Psychology of Business - Wages," System, XVIII (December, 1910), 610. The first article appeared in XVII (March, 1910), 252.

12 Psychological Bulletin, IX (November, 1912), 429. Strong was later a professor of psychology, George Peabody College for Teachers, and a member of the Committee on Classification of Personnel in the Army. 
The employer should see that each man had a chance to develop himself and was encouraged to do so. Scott noted that some large firms cultivated personal relationships through an employment or labor department.

A pleasant working environment would render the worker receptive to suggestions and cultivate in him a desire to please those with whom he worked, thus improving productivity. Pay was important because it satisfied the instincts of self preservation, for social distinction, and for acquisition. Its success as a motivator depended upon how well those fundamental instincts were satisfied and favorable attitudes created. The successful executive was motivated by the instinctive love of the game which could be cultivated through assignments that called for personal responsibility and initiative, that provided social prestige and approval, and that appealed to the individual as something important and useful.

Scott concluded this series with two articles on the influence of attitudes on learning and the development of experience. He presented learning curves based on touch typing, telegraphy, and learning the Russian language to show that improvement was not continuous. Habit was important for it reduced the demand upon voluntary attention which depended upon an exertion of the will. ${ }^{13}$

A reading of his Psychology of Advertising would show that Scott considered suggestion to have a stronger effect than other appeals to reason. Suggestion and suggestibility were of professional interest to him as evidenced by seven annual reviews of the literature on this subject over his name in the Psychological Bulletin, 1910 through 1916. Also, he described two of his own experiments in suggestibility working with beginning students in experimental psychology. ${ }^{14}$ Following Coe's example, he used hypnosis from time to time in class demonstrations. In 1909 he assisted physicians in treating patients at the North Shore Health Resort by placing them under hypnosis and speeding their recovery through psychological suggestions and re-education. This experience was the basis for a paper read before the Evanston Branch of the Chicago Medical Society in which he said "I am a profound believer in the power of the mind in causing and curing disease." 15

His book Influencing Men In Business had the theme that the power of suggestion was superior to an appeal to reason in typical 1911).

${ }^{18}$ The series was published as Increasing Human Efficiency In Business (New York,

${ }_{14}$ W. D. Scott, "Personal Differences in Suggestibility," Psychological Review, XVII (March, 1910), 147.

${ }^{15}$ Jacobson, Scott, 63.

BUSINESS HISTORY REVIEW 
business situations of inducing people to produce acceptable work, to enter your employment, or to buy your goods. Harry L. Hollingworth, professor of psychology at Columbia University, said in his review that the book was a clearly written and popular presentation of James' analyses. ${ }^{16}$

In the course of his studies, Scott became convinced that improvement in advertising was more than a matter of better copy; there was a need for better copy writers. Also, that advertising was but a part of selling and that there was a need for better salesmen. His interest turned to vocational selection, but the precise time he began this work is not clear, although he had identified selection as a problem in his articles on the psychology of business.

As an associate member of the National Association of Corporation Schools, Scott proposed to the executive committee that he make a study of the employment plans of the company members of the association. He wrote: ${ }^{17}$

The selecting of men is one of the important functions in business and yet one that has not received much scientific attention. I feel sure that the time is ripe for action for two reasons. The psychologists have during the past few years made distinct advance in Mental Tests. My proposal is this: You get from your Class A members data as to their methods of selecting men. Any statements as to actual experience and as to principles or methods will be very valuable. I would make a study of these data and would have some of the men from our School of Commerce go over them with me. We would try to criticize them constructively. Perhaps we could make some suggestions that would be worth while. We would try to indicate the good points used and thus be of assistance to all members of the organization.

This proposal was approved on February 26, 1914, and the desired information requested. Scott analyzed the forty-seven replies and presented a preliminary report to the 1914 convention. ${ }^{18}$ This study clearly marked Scott's activity in the field of employment psychology. He said in 1916 that he had been working on selection methods for two years. ${ }^{19}$

As there were but forty-nine company members in the association at the time of Scott's request, the response to his inquiry was excellent. The members were all large eastern companies and represented manufacturing, transportation, public utilities, com-

$16 \mathrm{~W}$. D. Scott, Influencing Men In Business (New York, 1911). Review in Psychological Bulletin, VIII (November, 1911), 398.

${ }^{17}$ National Association of Corporation Schools, Bulletin, I (March, 1914), 48. This is now Management Review.

${ }^{18}$ National Association of Corporation Schools, Bulletin, I (July, 1914), 41.

10 W. D. Scott, "Selection of Employees by Means of Quantitative Determinations," American Academy of Political and Social Science, Annals, LXV (May, 1916), 182. 
munications, construction, and distribution, including such names as National Cash Register, General Electric, New York Edison, and Montgomery Ward. The purpose of the association was to aid corporations in the education of their employees and increase the efficiency of both the individual employee and of industry. ${ }^{20}$

The American Tobacco Company furthered Scott's movement into personnel evaluation by engaging him in 1915 to help them improve their selection of salesmen. Scott brought six managers and thirty-six applicants for selling positions to Evanston where he could study their usual methods. He had each of the six managers interview all the applicants and rank order them from one (most likely to succeed) to thirty-six (least likely). Since it was the intention of the company to hire about half the applicants, it would stand to reason that the six managers ought to agree on those applicants in the upper half. But it worked out that for twenty-eight of the applicants the six managers could not agree on whether the applicant should be in the upper or lower half. This experiment convinced Scott of the unscientific nature of the interview as a selection device, so he proposed to replace it with a general intelligence test which he devised. This test measured not only the ability to learn but the verbal and mathematical ability needed to write up orders and reports. He also coached the managers to improve their interview technique. This work was described in an article in Advertising and Selling. ${ }^{21}$ A following article described how his tests were being used in a number of large companies, one being the Western Electric Company. ${ }^{22}$

Scott was also engaged by the Cheney Brothers Silk Company, South Manchester, Connecticut, the oldest and largest silk manufacturing firm in the world. He developed tests for production workers, clerks, time keepers, salesmen, and executives. In validating his tests for production workers he used workers of known ability selecting an equal number in three groups: those extremely efficient, workers unfit for the task, and workers of intermediate ratings. The ratings of ability were determined by combining the estimates of more than two of their superiors. The workers were then ranked, high to low, based upon the ratings of their superiors

\footnotetext{
20 National Association of Corporation Schools, Second Annual Convention: Papers, Reports, Bibliographies, and Discussions, Philadelphia, Pa., June 9-12, 1914. Company members were listed on p. 29.

21 W. D. Scott, "The Scientific Selection of Salesmen, Part I," Advertising and Selling, XXV (October, 1915), 5. Assisted by W. V. Bingham and G. M. Whipple he conducted a similar demonstration on July 8,1916 , with the same results. Salesmanship, IV (1916), 106.

${ }^{22}$ W. D. Scott, "The Scientific Selection of Salesmen, Part II," Advertising and Selling, XXV (November, 1915), 11.
} 
- this was the "firm rank." Scott then tested these workers and made a similar ranking based upon his test scores - the "test rank." He observed that the test rank agreed "perfectly" with the firm rank on the top seven workers, and "almost perfectly" on the bottom ten. While there was lack of agreement between the test rank and the firm rank on the middle nine workers, this agreement was better than that between the opinions of any two superiors. ${ }^{23}$

Horace L. Gardner, employment manager of Cheney Brothers, outlined their selection procedure as including: an initial interview, physical examination, mental tests and references, and an interview by the department foreman. He said that Scott's tests were a very valuable aid in the selection for mental qualities. ${ }^{24}$ Scott did similar work for the Clothcraft Shops, Cleveland, Ohio, and Mary Gilson, their employment manager, said that his work had convinced her that their factory work not only required manual dexterity but a higher standard of mentality than they had thought necessary. ${ }^{25}$

Scott developed four methods for validating his tests. The firm rank method was that used at Cheney Brothers. His second method was to test applicants, record the scores, and compare the test scores with actual performance on the job at some later date. $\mathrm{He}$ reported using this method with ten salesmen hired in April 1914. ${ }^{26}$ He used decoys or ringers in his third method. Salesmen of known performance, but unknown to the test administrator were tested along with the other applicants. The idea was that a good test should discriminate among salesmen whose performance was already known. ${ }^{27}$

His fourth method, apparently developed somewhat later, was called the "applicants-experts" method. Applicants for selling positions, after having been recommended for employment, were given a series of psychological tests for general intelligence, word building, completion, card sorting, and imagination. At the same time a number of successful salesmen in the same territory were also tested. Scott's comparison of the actual performance of the candidates, most of whom failed, with the performance of the suc-

${ }^{23}$ W. D. Scott, "The Scientific Selection of Salesmen, Part III," Advertising and Selling, XXV (December, 1915), 11.

${ }_{24}$ H. L. Gardner, "The Selection Problem of Cheney Brothers," U.S. Bureau of Labor Statistics, Bulletin No. 227 (October, 1917), 123.

${ }^{25}$ M. B. Gilson, "Work of the Employment and Service Department of the Clothcraft Shops," U.S. Bureau of Labor Statistics, Bulletin No. 227 (October, 1917), 144.

${ }_{20}$ Scott, Scientific Selection of Salesmen, Part III, 69.

27 Ibid., 70. The poor salesmen in this test had already been selected for dismissal because of poor performance. 
cessful salesmen showed that the tests did differentiate. This method served to corroborate the results of the three other methods, or as an alternate to them..$^{28}$

The uniqueness of Scott's procedure for validating his tests was that he measured against success in practice rather than against theory. He used the judgments and criteria of businessmen as his standard and they could readily understand his purpose. In contrast to Scott's pragmatic approach, Guy M. Whipple, a professor of education at the University of Illinois, said in 1916 that most of the efforts of the psychologists to measure the skills or abilities needed for a particular calling were so academic and theoretical as to make little impression on business men. ${ }^{29}$ Testing in industry has since followed closely the pattern set by Scott. ${ }^{30}$

Scott's interest in the selection of salesmen led to his taking leave of absence from Northwestern University to head the newly formed Bureau of Salesmanship Research at the Carnegie Institute of Technology. Walter V. Bingham, head of the division of applied psychology at Carnegie Institute, and Edward W. Woods, manager of the Pittsburgh agency of the Equitable Life Assurance Society and president of the National Association of Life Underwriters, had persuaded thirty large firms to participate in a cooperative study of salesmanship to include the best methods of selecting, developing and supervising them. Of the eighteen companies represented at the organizational meeting on May 25, 1916, six were life insurance companies, including Prudential and Metropolitan. The other twelve were manufacturers such as Westinghouse Electric and Manufacturing, H. J. Heinz, and Carnegie Steel. ${ }^{31}$ Scott said later that the thirty firms were compelled to employ 30,000 new salesmen each year to keep 48,000 positions filled. ${ }^{32}$

In recalling the creation of the Bureau, Bingham said in his autobiography: "There was a dearth of psychologists familiar with business operations. I finally persuaded Northwestern University to loan us Walter Dill Scott, who took up his duties in Pittsburgh on June 1, 1916, as the first American professor of applied psychology. His personal leadership coupled with his scientific preoccupations and his shrewd insight into business affairs were invaluable

\footnotetext{
28 W. D. Scott, "A Fourth Method of Checking Results in Vocational Selection," Journal of Applied Psychology, I (March, 1917), 61. All four methods were described. ${ }^{20}$ G. M. Whipple, "The Use of Mental Tests in Vocational Selection," Annals, LXV (May, 1916), 195.

${ }^{30} \mathrm{~L}$. W. Ferguson, The Heritage of Industrial Psychology, Volume 5, Bureau of Salesmanship Research, Walter Dill Scott, Director (Hartford, 1963), 61.

s1 Ibid., 55. The eighteen companies were named.

32 Scott, et al, Personnel Management (5th ed.), 246.
} 
in this movement to study live problems in management by the methods of psychology." 33

Scott brought to the Bureau his by-then well-developed selection procedure which considered personal history, personality, intelligence, technical ability, and physical condition. ${ }^{34}$ While he was seeking to "quantify" his selection methods at that time, he recognized the place of the interview for information on personality and preferred to combine the results of several interviews. He said later that there was no substitute for the interview in obtaining intimate or personal information for use in placement. Scott considered psychological tests as but one of the tools available for selection. $^{35}$

Seven research fellows assisted Scott in the work of the Bureau. $\mathrm{He}$ began the project by collecting information on the methods then being used by the participating firms for selecting their salesmen. This material was studied systematically and, within a year, the Bureau had developed five aids for the selection of salesmen: a personal history record, a model letter to former employers, an interviewer's scale, an interviewer's rating sheet, and a battery of five psychological tests. ${ }^{36}$ Although the initial work was concentrated on selection, work on the training of salesmen was planned as the next step.

The interviewer's scale became widely known as the "man-toman" rating scale because of the standard of comparison. The first version was ready for use in January 1917 and intended both for selecting and rating salesmen. Considerable time and effort were required to prepare the scale. A list of twenty-five names known to the rater was made. Selections for this list included five men who ranked from high to low in each of five traits: appearance, convincingness, industry, character, and value to the firm. Each trait was considered separately and the names of five known salesmen were selected as most representative of five ranks: highest, high, intermediate, low, and lowest. The complete scale consisted of five lists of five names each. Some duplication of names was permitted and former employees could be included if necessary. The concept underlying this scale was quite similar to that of the firm rank method Scott used for validating his tests.

ss C. Murchison (ed.), A History of Psychology in Autobiography, Volume 4 (Worcester, $1952), 13$.

s4 Scott, Selection of Employees (1916), 182.

${ }^{85}$ W. D. Scott and R. C. Clothier, Personnel Management (Chicago, 1923 ), 333.

${ }^{36}$ War Department, The Personnel System of the United States Army, Volume I, History of the Personnel System (Washington, 1919), 42. These tests measured general intelligence, range of information, facility in language, imagination, and speed and accuracy in clerical work. 
The interviewer, in evaluating an applicant or in rating a salesman, considered only one trait at a time. He matched the person being rated with one of the salesmen known to him and listed on the rating scale. Each rank for each trait had a numerical value, so the value corresponding to his evaluation was noted by the interviewer and entered on the rating sheet. After all five traits were separately evaluated the ratings were summed for a total rating. Scott recommended that each applicant be interviewed by at least three executives. This approach concentrated the attention of the interviewer on one essential trait at a time; provided a concrete standard for rating each trait; and, increased the accuracy of judgement, particularly when the independent judgements of several interviewers were combined. These concepts are still basic to merit rating. Scott considered that the scale could also measure the relative ability of the interviewers to judge men. ${ }^{37}$

World War I gave Scott a massive opportunity to employ and expand these methods. When war was declared, Scott and Bingham both suggested to Robert M. Yerkes, then president of the American Psychological Association, that psychologists should aid in the war effort. Yerkes called a meeting of the Council of the association for April 21, 1917, at the Walton Hotel in Philadelphia. ${ }^{38}$ A marked difference of opinion developed. The majority, including Yerkes, held to the view that primary emphasis should be placed on mental testing and that psychologists should work under the Surgeon General. Their interest focused on the opportunity for research to advance psychology. Scott believed that a more specific contribution could be made; that his rating scale held more promise than intelligence tests, particularly in the selection of officers. $^{39}$ His interest was in using the available knowledge of psychology to help the Army, with research a secondary interest. Also, he objected to psychologists working under the Surgeon General on the grounds that it would subordinate them to the psychiatrists and thus limit their scope and effectiveness. He believed that the psychologists should work under the direct supervision of some high official such as the Secretary of War, or the Chief of Staff. Bingham supported Scott in these views.

Scott decided to go it alone and seek to interest the Army in

${ }^{37}$ Ferguson, Bureau of Salesmanship Research, 57.

${ }^{88}$ L. W. Ferguson, The Heritage of Industrial Psychology, Volume 9, Psychology and The Army - Introduction of The Rating Scale (Hartford, 1963), 125. Roswell P. Angier, Knight Dunlap, and Herbert S. Langfeld were present with Scott, Bingham, and Yerkes. H. L. Hollingworth, a member, was absent.

${ }^{30}$ As early as April 10, 1917, Scott had considered the use of the aids in Army work. War Department, The Personnel System of the United States Army, Volume II, The Personnel Manual (Washington, 1919), 14. 
his rating scale. He returned to Pittsburgh and, by May 4, had developed A Rating Scale for Selecting Captains. ${ }^{40}$ He sent copies of this scale and the instructions for its use to a number of psychologists, including Paul S. Achilles who was an officer in training at Plattsburg. Scott approached the War Department through Frederick P. Keppel who was on leave from Columbia University and assistant to Secretary of War Newton D. Baker. Although he knew Keppel, Scott first wrote Edward L. Thorndike of Columbia University who wrote Keppel in turn. After discussing Scott's proposal with various officials of the War Department, Keppel suggested that he come to Washington. ${ }^{41}$

Scott spent his first week in Washington conferring with interested officers and discussing his scale. He improved the scale and tested the new version at Fort Myer, Virginia, on July 12. Although the scale was received with enthusiasm, further tests were considered desirable at Plattsburg, the headquarters of the Officers' Training Movement. This posed a problem, however, as Achilles had already forwarded his copy of the Scott rating scale through channels to the commanding officer at Plattsburg but the latter had not been interested.

At the Plattsburg conference, Scott pointed out that the scale was merely the embodiment of principle and that he had come to ask them to join him in creating a scale for the Army, not so much for their use as for use in the later camps. He explained the scale in detail and asked for suggestions to improve it. A point by point discussion clarified Scott's purpose but developed only minor changes in language. The scale was then endorsed by the commanding officer. ${ }^{42}$ Plattsburg was the only camp where Scott had to overcome resistance to the idea of his scale.

He returned to Washington on July 27 to prepare the version of his scale to be used by the Second Officer's Training Camps to begin in September 1917. Five essential qualities were rated on this version: personal, intelligence, physical, leadership, and general value to the service. ${ }^{43}$ That same day, Keppel made an appointment for Scott to see Secretary Baker to explain his scale. At this meeting, Scott emphasized that the rating scale was but one sample of what psychologists could do for the Army in personnel work. He suggested that a group of psychologists and experienced em-

${ }^{10}$ Ferguson, Introduction of The Rating Scale, 126.

41 War Department, History of The Personnel System, 45.

42 Ibid., 51.

43 Ibid., 52. Scott's first version included: appearance, military experience, influence over men, regard for authority, vigor, stability, judgment, and total value to the regiment. Most of the change came before the test at Fort Myer.

WALTER DILL SCOTT 161 
ployment managers be appointed to advise the Army on personnel problems, and he volunteered to assemble such a group. Baker liked the idea but would take no action until the Chief of Staff and the heads of the major bureaus had agreed. Scott obtained these approvals and submitted a formal proposal to Baker on July 30. His plan drew on his experience with the Bureau of Salesmanship Research and proposed a scientific staff, a group of civilian experts for research and planning, and a board of military representatives who would bring problems to this committee and who would help implement its recommendations. ${ }^{44}$ Formal approval was given on August 5, 1917.

Within six weeks, the Committee on the Classification of Personnel in the Army, under Scott's leadership, created and had in operation a classification and assignment system for the Army where none had existed before. At the time of the Armistice this system was staffed with more than 7,000 personnel specialists who had interviewed and classified more than 3,000,000 men. Of these, more than one-third were assigned where the Army could best use their special abilities. It was the largest personnel job ever attempted to that time.

Employment management, a movement advocating a centralized approach to personnel administration, had been in existence about six years at this time. Its evolution has been described by Eilbirt elsewhere. ${ }^{45}$ The scope of employment management was very much like that of a first class personnel department today. Scott was well acquainted with many of the leaders in this movement through his study for the National Association of Corporation Schools and he had read a paper before the third national conference. ${ }^{46}$ Douglas estimated that there were only a few hundred employment managers in 1917 and that they were of a very uneven character and ability. ${ }^{47}$ Scott selected Robert C. Clothier of the Curtis Publishing Company and Horace L. Gardner of Cheney Brothers Silk Company as the employment managers on his committee.

The Committee on the Classification of Personnel in the Army was organized with Scott as director, Bingham as executive secretary, the two employment managers, and eight university psycholo-

4Ibid., 56.

45 Henry Eilbirt, "The Development of Personnel Management in The United States," Business History Review, XXXIII (Autumn, 1959), 352.

${ }^{4}$ U.S. Bureau of Labor Statistics, Bulletin No. 227, 114.

17 P. H. Douglas, "Plant Administration of Labor," Journal of Political Economy, XXVII (July, 1919), 548, 550, 556.

162 BUSINESS HISTORY REVIEW 
gists. It worked directly under the Adjutant General of the Army. ${ }^{48}$ The first task for the committee was the preparation of rating scales for the several services based upon agreements which Scott had made before the committee was authorized. Beyond this, the general plan was to modify for Army use the aids developed by the Bureau of Salesmanship Research. As work began on revising the personal history record it soon became clear that no one in the Army had been charged with the responsibility for classifying the men of the first draft due to arrive in the camps early in September, and for assigning them so that best use could be made of their abilities. The Adjutant General directed the committee to undertake this task and gave it supervisory and executive responsibilities. ${ }^{49}$

The classification and assignment plan was based on six principles: The principle of functionalization dictated that the control and administration of personnel work should be the full time duty of a selected officer and his staff. The principle of human differences recognized the great variety and wide range of excellence in human traits. It required that each man be dealt with on an individual basis. The principle of definite personnel requirements called for a detailed statement of job requirements so that the qualifications of the man could be matched with the job needs. The principle of organization required a suitable organization to effect an adjustment between the personnel requirements and the available supply of men. The principle of economy of personnel dictated that each man be placed where he could be of greatest value to the service, rather than simply to match qualifications with job requirements. This called for priorities among requirements. The principle of morale meant that any transfer of personnel should consider the effect on the spirit of the man and of the organization. This called for a correct initial assignment to minimize later adjustments; following personal preferences when possible; and, taking pains to explain to the individual the necessity for his transfer when it did not coincide with his preference. ${ }^{50}$

Operation of the plan was decentralized to the sixteen National Army cantonments scheduled to receive the draft. Each camp commander designated a personnel officer, preferably with some knowledge of advanced personnel practices. Sixteen experienced employment managers were borrowed from industry for a ten-

49 Bingham summarized the work of this committee in "Army Personnel Work," Journal of Applied Psychology, III (March, 1919), 1.

${ }^{40}$ War Department, History of The Personnel System, 61.

so Ibid., 3-24. 
week period to get the program started. Short training conferences were held early in September to familiarize the new personnel officers and the civilian experts with the planned procedures. In less than six weeks the system was ready to receive the men, even if the margin was but a few hours. ${ }^{51}$

All the aids for selecting salesmen were modified for Army use. The personal history record became the Soldier's Qualification Card. The interviewer's scale and rating sheet became the Army Rating Scale. The battery of psychological tests laid the ground work for the Army Alpha Test. The model letter to former employers was intended to obtain information about a man's character, but was never used extensively. ${ }^{52}$

In the beginning, the interviewer sought to determine the degree of job skill through careful questioning, but this proved to be impossible. To meet this need, eighty-four oral trade tests were developed for the essential skills among Army requirements. The tests were based on the key word principle so that the test could be administered by an examiner with no personal knowledge of the trade. When a recruit claimed skill in such a trade, the examiner asked him questions from the manual. If the recruit responded with any of the specified key words, he was given credit for that question. A score based on questions answered determined the skill level possessed by the recruit. ${ }^{53}$

Scott's committee was not directly involved in mental testing, although each recruit was eventually assigned an intelligence rating which was posted to his qualification card. Mental testing was under the Surgeon General with Yerkes supervising the examinations. Coordination was obtained because Yerkes was also a member of Scott's committee. Scott considered that the use of intelligence and trade tests in the Army marked the first great step toward a real science of personnel work. ${ }^{54}$

The Army tables of organization were not useable for placement because the work was described by military titles. The first step in setting up personnel requirements was to convert the military

51 War Department, The Personnel Manual, 20.

52 Bingham said, "My first years in Pittsburgh proved to have been a rehearsal for the enormous task of military classification and assignment." He noted that the paper and pencil adult intelligence test developed by the Bureau was a forerunner of the Army Alpha. Murchison, History of Psychology, Volume 4, p. 14. Bingham worked with Yerkes in developing the Army Alpha.

${ }_{53}$ C. H. Crennan, editor of, The Annals, vol. 81 (January, 1919), considered trade tests a notable innovation, p. xii, as did Douglas, Plant Administration, 554.

54 War Department, History of The Personnel System, 135. Yerkes agreed later that the main value of mental testing was in placement. L. W. Ferguson, The Heritage of Industrial Psychology, Volume 8, Psychology and The Army-Examining Recruits (Hartford, 1963), 113.

\section{BUSINESS HISTORY REVIEW}


titles to civilian occupational titles, and to assign draftees on the basis of occupation. This was recognized as a stop-gap measure. Detailed personnel specifications were eventually prepared for every job in the Army. ${ }^{55}$ In making assignments, care was taken to balance units so that each was provided its share of occupational experience as well as its pro rata share of men of superior, average and inferior intelligence. This conserved the civilian experience brought into the Army and facilitated training. ${ }^{56}$

The Army Rating Scale was the principal tool in personnel work with officers, used both in selection and in promotion. It was first used as an aid in selecting men for commissions when they had completed an officer's training camp. By the time of the Armistice, all officers were being rated quarterly as a routine procedure. ${ }^{57}$ Scott was in personal charge of the planning and research work of the committee. Major research effort was intended to anticipate the future, study conditions and initiate improvements in operating procedure. A variety of studies were made, an example being "A Study of Officers' Ratings" which proved to be quite popular.

The final report of the Committee on the Classification of Personnel names Colonel Scott as the one "who first conceived the idea, and whose faith in the cause, coupled with his tremendous energy and devotion, enabled him to accomplish for the Army a truly distinguished service." Scott was awarded the Distinguished Service Medal when he left the service in $1919 .{ }^{58}$ As testimony to the work of Scott and his committee, the plan that was developed in 1917 was used again in World War II substantially without change. Procedures were up-dated in 1939 to conform to current practice in the mobilization planning. A new Army General Classification Test was developed to replace the Army Alpha. Psychologists again aided in personnel work, except that this time the committee retained its advisory character throughout the War. Bingham served as the chairman of this committee. ${ }^{59}$

Scott returned briefly to the Bureau of Salesmanship Research in 1919 but soon resigned to form the Scott Company in Philadelphia. His partners in this venture were Robert C. Clothier, Joseph W. Hayes, Louis B. Hopkins, Stanley B. Mathewson, and Beardsley Ruml, all former associates in the Committee on the Classification

\footnotetext{
${ }_{55}$ War Department, History of The Personnel System, 179-84.

56 A. M. Simons thought that this idea should be considered by industrial managers, Personnel Relations in Industry (New York, 1921), 90.

${ }^{57}$ War Department, History of the Personnel System, 559-64.

58 Ibid., 62. Scott was commissioned a colonel in the Adjutant General's Department on November 6, 1918.

${ }^{50}$ Murchison, History of Psychology, Volume 4, p. 22. The author of this paper participated in that revision.
} 
of Personnel. This was the first company of consulting psychologists in the field of industrial personnel.

Clothier had been employment manager of the Curtis Publishing Company, and during the war was directly responsible for the design and operation of the classification and assignment system. Examples of his work with the Scott Company include planning and organizing an occupational survey for the Army Air Service, ${ }^{60}$ setting up an employee representation plan for the Full Fashioned Hosiery Manufacturers Association, ${ }^{61}$ and installing a personnel program. ${ }^{2}$

The other four partners had worked in the trade test program under the committee. After the war, they worked with clients in the use of intelligence and special ability tests. Hopkins had been employment manager of the General Electric Plant at Pittsfield, Massachusetts. During the war he set up the trade test program assisted by Mathewson who had come from the Southern Bell Telephone and Telegraph Company, Atlanta. Hayes was a psychologist who had worked under Yerkes in developing and using the Army Alpha Test. He had been in charge of training officers to administer the trade tests. Ruml, also a psychologist, came from the Carnegie Institute of Technology and had been in charge of devising and standardizing the trade tests. ${ }^{63}$

Scott and his partners worked with more than forty large industrial firms between 1919 and 1923 extending to industry the knowledge gained in the Army. ${ }^{64}$ Their work covered the entire field of personnel management and was characterized by systematic research and the development of specific solutions to meet each client's needs. Their clients included manufacturing firms, public utilities, associations of manufacturers, government agencies, a bank, and a department store. Several of their clients were members of the National Association of Corporation Schools and the Bureau of Salesmanship Research, Westinghouse Electric and Manufacturing Company and Strawbridge and Clothier being in this group. In working with its first two clients, the Domestic Engineering Company and the Dayton Engineering Laboratories, the

${ }^{60}$ R. C. Clothier, "Organization for an Occupational Survey," Journal of Personnel Research, I (February, 1923), 427.

${ }^{61}$ L. W. Ferguson, "Industrial Psychology and Labor," in B. von Haller Gilmer (ed.), Walter Van Dyke Bingham Memorial Program (Pittsburgh, 1961), 17.

e2 "Strawbridge \& Clothier Adopt Modification of the Army Personnel System," National Association of Corporation Schools, Bulletin, VI (June, 1919), 268.

"s Beardsley Ruml, "The Extension of Selective Tests to Industry," Annals, 81 (January, 1919), 38. Donald G. Paterson and Beardsley Ruml, "The Extension of Rating Scale Theory and Technique," Psychological Bulletin, XVII (February, 1920), 80.

64 Ferguson, Industrial Psychology and Labor, 15.

BUSINESS HISTORY REVIEW 
Scott Company developed the principles which underlie all modern point systems of job evaluation. ${ }^{65}$ The man-to-man rating scale was modified for rating foremen and executives, and widely used for a time. As the preparation of the master scale proved to be too difficult in such use, a simplified version "The Graphic Rating Scale" was developed. ${ }^{68}$ Bruce V. Moore and George W. Hartman said that the activities of the Scott Company served more than any other single factor to familiarize American businessmen with the enlightened practice of the War Department. ${ }^{67}$

Both the philosophy and experience of Scott and his partners were perpetuated in Personnel Management (1923). This philosophy included the human conception of labor which can be traced back to Scott's articles on the psychology of business. He emphasized again that lack of efficiency and absence of worker satisfaction were due to management methods which placed more emphasis upon the work than upon the person doing the work. Such managers failed to recognize fundamental human cravings: for achievement; for freedom from fear; for reasonable leisure; and, for a sense of worthwhileness. Efficiency could not be achieved at the expense of worker satisfaction, nor could true satisfaction be achieved at the expense of efficiency. ${ }^{68}$

The human conception of labor stated that cooperation between management and labor was essential to efficient production. This cooperation could be attained only when the minds of the workers were involved in their work as well as their bodies. Workers had certain inalienable rights as human beings and industry not only had the duty to recognize such rights, but a moral obligation to encourage and help the worker to make as much of his life as possible. An industrial concern had three basic obligations: to its stockholders, to its customers and the public, and to its employees. ${ }^{69}$ The chapters on psychological tests were based on Scott's work prior to 1923. He made no unusual claims for such tests considering them convenient tools in studying human behavior either for making a more accurate selection, or for more effective supervision. ${ }^{70}$

In his work with the Scott Company, Scott worked with two

65 Ibid., 8.

${ }^{66}$ D. G. Paterson, "The Scott Company's Graphic Rating Scale," Journal of Personnel Research, I (Dec. 1922-Jan. 1923), 361. Several articles on the work of the Scott Company may be found in this volume.

${ }^{67}$ Bruce V. Moore and George W. Hartman, Readings in Industrial Psychology (New York (1931), 6.

os Scott and Clothier, Personnel Management (1923), 21.

60 Ibid., 7, 60.

70 Ibid., 259. 
clients in setting up employee representation plans, for him a new field of personnel work. His model was the well-known agreement between Hart, Schaffner \& Marx and the Amalgamated Clothing Workers of America, which had been in effect for about eight years. The essence of this plan was equal participation of the employer and the union in resolving conflicts growing out of the work situation. Working with the Chicago Market Committee, Scott developed a similar plan for the entire men's clothing industry in Chicago. The next year, 1920, he did similar work with the Chicago Foundrymen's Association. The later study was described in an appendix to Personnel Management. ${ }^{71}$ In both of these studies, Scott advocated a positive or cooperative attitude by management toward labor.

William R. Spriegel, who spent many hours with Scott discussing personnel management, said that Scott did not believe that trade unions were necessary to cooperation between management and labor because he considered them to be natural partners. However, he did recognize that unions might be necessary when workers had to deal with unenlightened managers. Scott was well aware of the general disinterest among managers toward scientific personnel work, and their opposition to trade unions. He told Spriegel that he was often critized by businessmen as being too liberal in his beliefs. Spriegel characterized Scott as a man of high principle and deeply religious - a Christian gentleman in the fullest sense of the word. He was modest and had a strong sense of social justice. $^{72}$

Scott was also criticized by many of his academic colleagues for his keen interest in business affairs, although some later changed their views. He was elected president of the American Psychological Association in 1918. His presidential address summarizing changes in personnel practice resulting from applied psychology was, in a modest way, a recital of his work. He noted six changes, the first and most important was the principle that individuals were different. His second point was the growing recognition that human behavior was based more on sentiment than on logic. The third change was the recognition of a double responsibility in industrial training, not only to provide an educative experience but to help the individual make the most of it. The biological relationship between the worker and his work was his fourth noted change. This was a recognition of the fact that the worker in his work was a

71 Ibid., 598.

72 Personal interview with William R. Spriegel, distinguished professor of management, the University of Texas at Austin, December 1967. 
unit, a living developing productive complex. His final point was that vocational guidance had become more scientific because of improvements in individual testing and a better analysis of the available vocations..$^{73}$

In retrospect, thus, the origin of Scott's interest in business appears complex. There was the obvious challenge in solving practical problems using his laboratory and knowledge, with the resulting social results: in 1911 he said, "The executive who develops novices into experts and the company which transforms mere 'handy men' into mechanics are public benefactors because of the service rendered to the country and their men." 74 He was also a superb teacher and sought to stimulate his students toward independent research and thinking, and to emphasize the importance of the functional application of knowledge. ${ }^{75}$ Scott no doubt viewed business problems as teaching resources. Gilson, in her autobiography, refers to "Scott and his crew" testing employees at Clothcraft Shops and her emphasis would imply such interest. ${ }^{76}$ If this be true, Scott needed business problems for his kind of teaching and experimentation, while business needed the help that such studies could afford - a happy combination at a time when both applied psychology and industry were growing rapidly. This view is illustrated by the educational experience afforded the seven research fellows who worked with Scott in the Bureau of Salesmanship Research.

Scott's importance as an industrial psychologist rests upon his work in advertising and personnel management. His pioneering work in advertising was well recognized by 1912 , but there is scant reference in the literature to his personal contributions to personnel management other than to his textbook published in 1923. In that book, his personal contributions were not identified.

In personnel management, Scott developed a basic philosophy for dealing with personal relationships in the workplace - the human conception toward labor. At the time his philosophy was developed (1910) there were relatively few centralized labor departments. It was two years later that the Boston Employment Manager's Association was organized. As far as this writer can determine, Scott's study of the psychology of business was the first comprehensive treatment of human behavior in the work situa-

\footnotetext{
${ }^{73}$ W. D. Scott, "Changes in Some of Our Conceptions and Practices of Personnel," Psychological Review, XXVII (March, 1920), 86. Edward B. Titchener, professor of psychology, Cornell University, was one of those who criticized Scott and later changed his views. Jacobson, Scott, 47. 162.

74 W. D. Scott, "The Rate of Improvement in Efficiency," System, XX (August, 1911),

75 Jacobson, Scott, 52.

${ }^{76}$ M. B. Gilson, What's Past Is Prologue (New York, 1940), 65.
} 
tion in the United States. He early identified selection as essential for the improvement of motivation and productivity, and his later work on selection was in this context.

In the field of selection, Scott sought to identify the best of the available tools actually used by business firms, to improve them, and to supplement them with psychological tests, recognizing that such tests were but one element in a procedure. His tests were developed through criteria that the business men could understand, success on the job. His ability to convince businessmen that his tests could help them in their selection problems was a contribution in itself because it served to enhance the stature of psychology in their minds. His man-to-man rating scale was unique and his concepts for guiding judgement in merit rating are basic tools of business practice today.

Scott crystallized the best of existing knowledge when he constructed the personnel system for the Army. He was able to do so in a very short time because he knew where to get qualified people, a by-product of his work with business. The advanced personnel practices used by the Army were refined and tested during World War I. This experience was later extended to business and industry through the work of the Scott Company and in his book Personnel Management. Although Scott became president of Northwestern University in 1920, he continued his keen interest in personnel matters and was active in keeping his book up to date through its fifth edition (1954)..$^{77}$

On Scott's eightieth birthday, May 1, 1949, Bingham saluted him as the "Pioneer of Personnel Psychology" and for his half-century of leadership in practical psychology. ${ }^{78}$ As historians increasingly examine the premises and practice of American business management in the early twentieth century, they must inevitably encounter and appraise the concepts and techniques which Scott and his associates contributed to the process of change.

${ }^{77}$ Interview with Spriegel December 1967.

78 W. V. Bingham, "Salute to the Pioneer of Personnel Psychology," Personnel Psychology, II (Summer, 1949), 274. Spriegel said that Bingham and Scott had a warm and deep liking and respect for each other, both personally and professionally. 